Research Article

\title{
Effect of Supplementation of Fermented Yeast Culture on Hormones and Their Receptors on Exposure to Higher Temperature and on Production Performance after Exposure in Nicobari Chickens
}

\author{
A. L. Nidamanuri (iD, Lawrence Leslie Leo Prince, S. P. Yadav, T. K. Bhattacharya, \\ S. R. R. Konadaka, and S. K. Bhanja
}

Directorate of Poultry Research, Rajendranagar, Hyderabad, Telangana State, India

Correspondence should be addressed to A. L. Nidamanuri; antianand@gmail.com

Received 17 February 2021; Revised 12 May 2021; Accepted 24 July 2021; Published 4 August 2021

Academic Editor: Ma gorzata Kotula Balak

Copyright (c) 2021 A. L. Nidamanuri et al. This is an open access article distributed under the Creative Commons Attribution License, which permits unrestricted use, distribution, and reproduction in any medium, provided the original work is properly cited.

\begin{abstract}
Heat stress (HS) affects the production performance in chickens and causes economic loss to the producers. Most of the studies have been conducted on and for the welfare of broilers. We still lack information on the physiological parameters being affected during chronic heat stress in layers. To fill this gap, the present study evaluated the effect of heat stress (induced in the chamber) during the prelaying period (21-23 weeks) on plasma levels of the hormones leptin and ghrelin and GH and expression of the respective receptors and heat stress markers. Three groups were considered, one at room temperature (CR) and the other two groups $\left(\mathrm{SH}\right.$ and $\mathrm{CH}$ ) subjected to heat stress at $39^{\circ} \mathrm{C}$ for four hours for three weeks (21-23 weeks of age). The $\mathrm{SH}$ group ( $\mathrm{SH}$ ) feed was supplemented with fermented yeast culture (FYC, $700 \mathrm{mg} / \mathrm{kg}$ ), whereas the $\mathrm{CH}$ group was devoid of it. After that, all the groups were shifted to shed under natural ambient conditions till 31 weeks of age. Studies were restricted to production performance only. Feed offered without yeast culture ( $\mathrm{CH}$ group) had a smaller concentration of plasma hormones $(P<0.01)$ and increased expression fold of the hormone receptors $(P<0.01)$. Further, the group also presented higher liver AMP kinase enzyme, plasma MDA (malondialdehyde), and cholesterol concentrations. These changes likely explained the decrease in feed intake and the $\mathrm{CH}$ group's body weight and further reduced the production performance during the laying period. Supplementation with FYC to birds had an opposite effect on the above-mentioned parameters, reducing HS effects. In summary, supplementation with FYC $(700 \mathrm{mg} / \mathrm{kg})$ maintained physiological parameters as in the CR group under HS conditions and negated adverse effects on parameters both before and during laying periods.
\end{abstract}

\section{Introduction}

The consequences of heat stress (HS) on chickens attract many researchers' attention $[1,2]$. Nowadays, we know the impact on the physiological parameters, notably, increased body core temperature, reduced feed intake, alteration of endocrine, and reproductive functions. Heat stress (HS) causes enormous economic losses in the poultry industry $[3,4]$. If the temperature rises above the critical threshold, the birds experience stress, thus altering their physiological functions. Besides, constant high temperature becomes more deleterious to birds than cyclic or alternating temperatures [5]. It leads to decreased feed intake and egg production and higher mortality $[6,7]$.

In the last two to three years, a number of reports with respect to the amelioration of heat stress are available. Reports are based on amelioration of heat stress by supplementation of herbal products, prebiotics, postbiotics, probiotics, minerals, enzymes, and vitamins [8] to chickens [8-16]. Otherwise, also there are a number of feed additives routinely used in poultry feed, such as antibiotics, probiotics, oligosaccharides, enzymes, and organic acids $[17,18]$, for 
promoting growth through their potential effect in increasing feed intake $[19,20]$. Most of the work is concentrated on the welfare of broilers.

A study on broilers reported that chronic heat exposure significantly increased cloacal temperatures and respiration rates when compared to the control group. Even in layer reports that are available with respect to amelioration of heat stress, they have concentrated on the effects of supplement only during the laying period. The present work describes the effect of applied heat stress (HS) during prelaying on the physiological parameters, especially the effect on mentioned hormones and their receptors, which has not been reported, and their posteffect in terms of decreased production performance has also been not reported. The present study reports that a supplement like FYC which has not been used for alleviation of heat stress is able to increase the production performance by reversing the effects of HS through modulation of hormones, metabolites, enzymes, and gene expression.

Additionally, it is reported that heat stress elevated ghrelin concentrations in serum and the intestine [21]. In mammals, ghrelin is usually described as an orexigenic hormone whose concentration increases during calorie restriction [22]. In chickens, ghrelin plays a distinct role. Exposure to heat decreased the plasma ghrelin level [23]. The short- and long-term environmental heat affect endocrine glands and, in turn, hormones, which further causes a decline in plasma levels after prolonged exposure. The reports regarding the effects of heat stress on hormones in broilers are many, but studies reflecting the impact on the mentioned parameters in layers are lacking. Another essential parameter affected by heat stress is the AMP kinase (AMPK) enzyme. The AMPK is one of the primary cellular energy sensors [24] and an intracellular low-energy warning system [25].

Heat stress induces an increase in intestinal permeability that is associated with massive generalized sloughing of epithelial layer from the villus tips and lysis of intestinal epithelial cells, indicating that the increase in intestinal permeability is due to the extensive damage of the epithelial surface [26]. Yeast cell walls are beneficial as natural feed additives and are widely used in poultry diets [27-29]. Yeast culture (YC) is a natural yeast fermentation product that includes yeast cells, vitamins, peptides, amino acids, and proteins [30]. Some other feed additives are also used to alleviate heat stress, such as trace elements, vitamins, and probiotics [31].

Liver plays an important role in digestion and metabolism, regulating the production, storage, and release of lipids, carbohydrates, and proteins [32]. In chickens, leptin is expressed mainly in the liver, where its receptor gene expression has also been reported, and in adipose tissue [33].

Magnum is one of the regions in the chicken oviduct which produces egg white. Though $88 \%$ of the albumen is water, this component of the egg contributes more than $60 \%$ to the total egg weight which is an essential quality of an egg [34]. Hrabia et al. [35] have demonstrated differential mRNA expression and protein localization of GH receptors in the infundibulum, magnum, isthmus, and shell gland of laying hens.
Nicobari is one of the indigenous breeds of chickens [36]. Nicobari fowl is an endangered breed of the Andaman and Nicobar Islands and produces the highest number of eggs among India's indigenous chicken breeds [37]. Hence, it becomes crucial to study physiological parameters' modulation when these birds are subjected to heat stress.

The current study hypothesizes that heat stress during the prelaying period affects production performance during the laying period. Continuous exposure to higher ambient temperature under controlled conditions is more effective compared to normal varying temperatures and may modulate the level of plasma hormones, metabolites, enzymes, and tissue gene expression. A supplement like FYC may be beneficial by removing the adverse effects of heat stress on the mentioned parameters, during the prelaying period (heat stress under controlled conditions) by modulating physiological parameters, and further on ovarian functions during the natural environmental conditions.

\section{Materials and Methods}

2.1. Animals and Experimental Setup. Nicobari chickens were maintained at an experimental poultry farm, ICARDirectorate of Poultry Research, Rajendranagar, Hyderabad, India. The Institutional Animal Ethics committee approved all experimental procedures conducted in this study. At the beginning of the experiment, birds of 18 weeks of age were randomly selected from the farm and maintained in individual cages with four to five chickens in a group in a cage. The cages were arranged in 3 tiers with two cages per tier and were placed on wheels. Before the experiment began, the birds were placed in the cages for one week to acclimatize to the new surroundings. From week 19 till the beginning of the 21st week, birds were gradually acclimatized to higher temperatures by raising the temperature from 37 to $39^{\circ} \mathrm{C}$. Three groups of birds were maintained. The number of birds in each group was thirty. Each group had five replicates with six birds in each group. The first group was the control group (CR), which was maintained at room temperature, the temperature varying between 22 and $26^{\circ} \mathrm{C}$ during the daytime. The second $(\mathrm{CH})$ and third $(\mathrm{SH})$ groups were exposed to a controlled temperature chamber continuously at $39^{\circ} \mathrm{C}$ for four hours ( 11 am to $3 \mathrm{pm}$ ) during three weeks starting from 21 weeks of age till the birds attained 23 weeks of age. $\mathrm{CH}$ group was offered feed devoid of supplement FYC, and $\mathrm{SH}$ was provided with FYC (Unigrow, Nurture Organics, New Delhi) at $700 \mathrm{mg} / \mathrm{kg}$ feed according to the manufacturer's instructions. The dose was standardized based on a pilot study conducted at our farm. The amount of feed in the form of mash (based on maize and soya, Table 1) [38] provided was $90 \mathrm{~g} / \mathrm{bird} /$ day, and water was provided ad libitum. After exposure to $39^{\circ} \mathrm{C}$ temperature, they were exposed to cyclic ambient room temperature. The humidity in the chamber was adjusted to $50 \%$ during the experiment. A regime of $16 \mathrm{~h}$ light was provided and all the chickens were kept under uniform light management conditions.

Initially, the chamber's temperature was increased to $32^{\circ} \mathrm{C}$; birds of $\mathrm{CH}$ and $\mathrm{SH}$ groups, placed in the cages, were shifted to the chamber where the temperature was set to 
TABle 1: Composition of feed ( $\mathrm{g} / \mathrm{kg}$ ) for layers ${ }^{\mathrm{a}}$.

\begin{tabular}{lcc}
\hline Components of diet & Layer grower & Layer breeder \\
\hline Maize & 560.5 & 613.9 \\
Soybean meal & 240.9 & 247.4 \\
DORB $^{\mathrm{b}}$ & 153.0 & 4.9 \\
Stone grit $^{\mathrm{c}}$ & 18.6 & 109.0 \\
DCP $^{\mathrm{c}}$ & 16.6 & 15.0 \\
Salt & 3.5 & 3.5 \\
Sodium bicarbonate & 1.0 & 1.0 \\
DL-methionine & 1.1 & 1.0 \\
L-lysine & 0 & 0 \\
Trace minerals & 1.5 & 1.0 \\
Vitamin premix & 0.25 & 2.5 \\
Choline chloride & 1.0 & 1.0 \\
Toxin binder & 1.0 & 0 \\
Tylosin & 0.5 & 0 \\
Coccidiostat & 0.5 & 0 \\
\hline
\end{tabular}

${ }^{a}$ Panda et al. [38]. ${ }^{b}$ DORB: deoiled rice bran. ${ }^{c}$ DCP: dicalcium phosphate.

$32^{\circ} \mathrm{C}$. Further, the temperature was raised to $39^{\circ} \mathrm{C}$ at a rate of $2^{\circ} \mathrm{C}$ for every half an hour. The birds were then maintained at $39^{\circ} \mathrm{C}$ for four hours. Similarly, at the end of the exposure, the temperature was brought down slowly to $32^{\circ} \mathrm{C}$, and then the birds were shifted to a room at ambient temperature. Care was taken to avoid spillage of feed and water. After moving them to room temperature, the water was replaced with normal drinking water. Rectal temperature was recorded with the help of a clinical thermometer. The thermometer was introduced into the cloaca $1.5 \mathrm{~cm}$ deep inside and allowed to stabilize before recording temperature. In each experiment, temperature values were recorded from five birds at random of each experimental unit for twenty-one days at 9 am and 4 pm, respectively. Exposure time used to get over by $4 \mathrm{pm}$.

2.2. Estimation of Body Weight, Feed Intake, and Egg Production Parameters. Body weight was recorded weekly for ten birds taken at random from 21 to 23 weeks of age during the course of exposure and further average value was estimated for fortnight interval starting from 24 weeks till the birds attained 29 weeks of age after exposure to a higher temperature. After three weeks of exposure, the birds were shifted to individual cages, and then they were exposed to ambient room temperature during summer in the shed.

Feed refusal was recorded every week to calculate feed intake every day, and average feed intake/bird/day for a week was estimated. From 25 to 29 weeks of age, average feed intake (FI) was estimated for 14-day intervals and expressed as feed intake/bird/day. The ambient temperature remained at the peak from 11.00 am to $3.00 \mathrm{pm}$, and peak temperature varied from 32 to $36^{\circ} \mathrm{C}$ (March-April) in the shed. The study on egg production continued till 30 weeks of age, where the effect of controlled heat stress during the prelaying period was observed during the laying period. Further, the effect of supplementation was also evaluated. Supplementation continued after exposure also, during the laying period to the SH group till 30 weeks of age. The number of eggs laid and the eggs' weight were recorded every day for the three groups.
2.3. Collection of Blood Samples, Processing, and Estimation of Plasma Parameters. At 10 and 20 days from the beginning of the experiment, at the end of exposure to $39^{\circ} \mathrm{C}, 1.5-2 \mathrm{ml}$ of blood was drawn from the wing vein of six birds from each group into EDTA rinsed tubes. The blood was immediately centrifuged at $3000 \mathrm{rpm}$ for $12 \mathrm{~min}$. The plasma was separated and stored at $-20^{\circ} \mathrm{C}$ to further analyze leptin (E12L0038) and ghrelin (E12G0013) hormones and GH (E12G0165), using commercial EIA kits (BlueGene Biotech, chicken Elisa kits, Shanghai, China); intra- and interassay variation was $<7 \%$. Plasma cholesterol (E03C0745), MDA (E03M0023), and liver AMP kinase (E12P0187) enzyme concentration were analyzed using commercial kits procured from BlueGene Biotech Co., Shanghai, China. The mentioned parameters were estimated according to the manufacturer's protocol.

2.4. Collection of Tissue Samples and Processing for Quantification of Different Parameters. Liver, magnum, and jejunum tissue samples were collected from randomly selected birds from each group and processed as described by Anand Laxmi et al. [39] after sacrificing five birds from each group at 10 and $20 \mathrm{~d}$ of the experiment. Chicken liver and magnum samples were processed for studies on the expression of leptin receptor (LEPR), ghrelin receptor (GSHR), and growth hormone receptor (GHR), whereas histological studies were conducted on jejunum samples to observe the severity of necrosis.

Magnum is a region of the oviduct extending between infundibulum and isthmus. Liver tissue was also processed for estimation of the concentration of enzyme AMP kinase, which was analyzed using commercial kits procured from BlueGene Biotech Co., Shanghai, China. Enzyme was estimated according to the manufacturer's protocol.

Jejunum samples for the histological study were processed as given by Quinteiro-Filho et al. [40]. Jejunum region extends from the duodenal loop to Meckel's diverticulum. Briefly, for histopathological studies on jejunum, the jejunum portion of the digestive tract was excised and cleaned from the sacrificed birds of each group. The contents of the jejunum were gently removed. The tissue was fixed in 10\% formaldehyde. Samples were kept in Bouin's solution and dehydrated in a graded series of alcohol. Finally, after embedding each specimen in paraffin wax, sections were fixed and stained with hematoxylin-eosin. Further, the slides were observed under a light microscope at 400x magnification to observe the villus' morphology and necrosis. The severity of the necrosis was graded as medium $(++)$, mild $(+)$, and normal $( \pm)$.

2.5. Isolation of RNA and Quantitative Real-Time PCR. Total RNA was isolated from liver and magnum tissue (100 mg approx.) using Trizol. cDNA was synthesized using 1 ug of RNA with the help of a First-Strand cDNA kit (Thermo Fisher Scientific Co.). The primers were got synthesized by Chromous Co., Bangalore, India (Table 2). Before proceeding on to real-time PCR, the primers were 
TABLE 2: Sequence of the primers.

\begin{tabular}{|c|c|c|c|}
\hline Genes & Sequence of forward $(\mathrm{F})$ and reverse $(\mathrm{R})$ primers & Size of the PCR product (bp) & Annealing temperature $(\mathrm{oC})$ \\
\hline Leptin R & $\begin{array}{l}\text { F 5'-CGGACTACCTCATGAAGATCCTGAC-3' } \\
\text { R 5'-GCCAATGGTGATGACCTGACCATC-3' }\end{array}$ & 162 & 55 \\
\hline GSHR & $\begin{array}{l}\text { F 5'-CTGCAAGCTCTTCCAGTTCATCAGC-3' } \\
\text { R } 5^{\prime} \text {-CCAGAGGATGAGGATGACCAGCTTG-3' }\end{array}$ & 158 & 55 \\
\hline GH R & $\begin{array}{c}\text { F } 5^{\prime} \text {-TCAGAAAGGATGGATTACTCTGGAGTATG - } 3^{\prime} \\
\text { R } 5^{\prime} \text {-CGGAGGTACGTTGTCTTGATCGGAC-3' }\end{array}$ & 161 & 55 \\
\hline Actin $\beta$ & $\begin{array}{c}\text { F 5'-CGGACTACCTCATGAAGATCCTGAC-3' } \\
\text { R 5'-GCCAATGGTGATGACCTGACCATC- } 3^{\prime}\end{array}$ & 197 & 55 \\
\hline
\end{tabular}

tested for the formation of respective gene products by the standardized PCR protocol [39] as conducted previously.

Further qPCR or gene expression studies for hormone receptors in the liver and magnum were also conducted. The messenger RNA (mRNA) expression of target genes was evaluated by real-time PCR. Real-time quantitative PCR was conducted using the SYBR ${ }^{\circledR}$ Green dye method and the SYBR Premix (InCell Technologies, Hyderabad) on a 7500 real-time PCR instrument (ABI, USA). The actin gene was utilized as a housekeeping gene to normalize the expression data of the target genes. The PCR program was operated as follows: $95^{\circ} \mathrm{C}$ for $60 \mathrm{~s}, 40$ cycles of $95^{\circ} \mathrm{C}$ for $30 \mathrm{~s}$, and $58^{\circ} \mathrm{C}$ for the $30^{\circ} \mathrm{s}$. Each reaction for a gene was repeated three times. The relative gene expression was calculated using the 2- $\Delta \Delta C \mathrm{~T}$ method [41].

Studies on hormone levels and gene expression studies were restricted to three weeks (the age of the birds was 21-23 weeks). Comparison of gene expression studies for hormone receptors was restricted to the $\mathrm{CH}$ and $\mathrm{SH}$ groups only. Further, after exposure trials, they were shifted to individual cages in the farm, where they were exposed to ambient cyclic room temperature during summer, which coincided with the birds' laying period. The effect of high ambient temperature (under controlled conditions) during the prelaying period was observed on body weight and egg production from 24 weeks onwards, which was the postexposure period during the summer season in the poultry shed.

2.6. Statistical Analysis. The effects of three treatments heat stress with and without supplement and also negative control (without stress and supplement) on hormones, receptors, and metabolites were done using one-way ANOVA. Birds were randomly assigned and selected from the different groups for the experiment and sampling purposes. Data were analyzed by analysis of variance (ANOVA) using the general linear model procedure (GLM) of SPSS 12 for Windows. LSD was used for pairwise comparison of the least square means $P<0.05$ [42].

\section{Results}

3.1. Cloacal Temperatures and Plasma Hormones. The average cloacal temperatures recorded from 21 to 23 weeks of age at 9 am at R.T. in the shed were $41.2,41.3$, and $41.2^{\circ} \mathrm{C}$, whereas at $5 \mathrm{pm}$ at the end of the exposure, the temperatures were $41.4,42.3$, and $42.4^{\circ} \mathrm{C}$ for the $\mathrm{CR}, \mathrm{CH}$, and $\mathrm{SH}$ groups, respectively. The analysis of plasma leptin hormone revealed that plasma concentration in the $\mathrm{CH}$ group was significantly less $(P<0.01)$ when compared to CR $(-69.8 \%$ on day 10 and $-50.5 \%$ on day 20$)$ and $\mathrm{SH}(-72.8 \%$ on day 10 and $-55.7 \%$ on day 20) (Table 3). Besides, the concentration of ghrelin hormone was significantly $(P<0.01$, Table 2$)$ less at both 10 and 20-day intervals when compared to the values in the CR $(-50.2 \%$ and $-26.2 \%)$ and SH group $(-50.9 \%$ and $-12.45 \%)$. The statistical difference was observed on day 20 only, being greater in the CR group (Table 2). The plasma GH hormone analysis revealed that both the $\mathrm{CH}$ and $\mathrm{SH}$ groups showed higher concentrations than the CR group at the 10-day interval. However, at the 20-day intervals, it was observed that the values in $\mathrm{CH}$ dropped to $2.83 \pm 0.11$ that represented a significant reduction $(P<0.01)$ when compared to the values in $\mathrm{CR}(-23.7 \%)$ and $\mathrm{SH}(-23.5 \%)$ (Table 3$)$.

3.2. Plasma MDA and Cholesterol. The supplementation of FYC reduced plasma MDA levels $(P<0.01$; Table 3$)$. The SH group presented $-40.8 \%$ plasma MDA concentration in relation to the $\mathrm{CH}$ group and $-27.2 \%$ with regard to the $\mathrm{CR}$ group on day 10. Similar results were also found on day 20, where the $\mathrm{SH}$ group presented $30.7 \%$ less plasma MDA than the $\mathrm{CH}$ group and $6.0 \%$ less than the CR group. Supplementation of FYC also contributed to a change in the levels of plasma cholesterol (Table 3). On day 10, the $\mathrm{SH}$ group showed $25.8 \%$ and $25.2 \%$ more cholesterol than the $\mathrm{CH}$ and $\mathrm{CR}$ groups, respectively. However, mean $\pm \mathrm{SE}$ values for day 20 revealed that the cholesterol concentrations in $\mathrm{SH}$ did not differ statistically from the CR group and reduced $13.1 \%$ concerning the $\mathrm{CH}$ group.

3.3. Liver AMP Kinase Enzyme. Further upon analysis of liver AMP kinase enzyme, levels did not show any statistical difference between the three treatments on day 10 . However, at 20 days, it was observed that the FYC treatment reduced AMP kinase levels by $22.4 \%$ compared to the $\mathrm{CH}$ and $13.6 \%$ compared to the CR treatment groups $(P<0.05$; Table 3$)$.

3.4. Production Performance. The supplementation with FYC affected the body weight (BW) of Nicobari chickens, but statistical differences became detectable after 22 weeks of age (Table 4). The difference in BW between the $\mathrm{CH}$ and $\mathrm{CR}$ groups was not significant at any age. Compared to $\mathrm{CH}$, the $\mathrm{SH}$ treatment represents a gain in BW that ranged between 3.9 and $6.1 \%$, whereas, compared to CR treatment, the BW gain ranged between 4.7 and 5.8\% from 22-29-week-old 
TABLE 3: Mean levels of hormones, metabolites, and liver enzymes of Nicobari chickens subjected to different treatments.

\begin{tabular}{|c|c|c|c|}
\hline Days 1 & $\mathrm{CR}^{2}$ & $\mathrm{CH}^{2}$ & $\mathrm{SH}^{2}$ \\
\hline & Plasma leptin (ng/mL) & & \\
\hline 10 & $3.34^{\mathrm{a}} \pm 0.14$ & $1.04^{\mathrm{b}} \pm 0.12$ & $3.83^{\mathrm{c}} \pm 0.11$ \\
\hline \multirow[t]{2}{*}{20} & $3.66^{\mathrm{a}} \pm 0.12$ & $1.81^{\mathrm{b}} \pm 0.09$ & $4.09^{\mathrm{c}} \pm 0.10$ \\
\hline & Plasma ghrelin $(\mathrm{pg} / \mathrm{mL})$ & & \\
\hline 10 & $61.39^{\mathrm{a}} \pm 0.92$ & $30.58^{\mathrm{b}} \pm 0.81$ & $62.27^{\mathrm{a}} \pm 1.34$ \\
\hline \multirow[t]{2}{*}{20} & $75.74^{\mathrm{a}} \pm 0.75$ & $55.91^{\mathrm{b}} \pm 0.87$ & $63.86^{\mathrm{c}} \pm 1.5$ \\
\hline & Plasma GH (ng/mL) & & \\
\hline 10 & $3.09^{\mathrm{a}} \pm 0.12$ & $4.07^{\mathrm{b}} \pm 0.15$ & $4.12^{\mathrm{b}} \pm 0.11$ \\
\hline \multirow[t]{2}{*}{20} & $3.71^{\mathrm{a}} \pm 0.12$ & $2.83^{\mathrm{b}} \pm 0.11$ & $3.70^{\mathrm{a}} \pm 0.14$ \\
\hline & Plasma MDA $(\mu \mathrm{M} / \mathrm{mL})$ & & \\
\hline 10 & $11.33^{\mathrm{a}} \pm 0.6$ & $13.94^{\mathrm{b}} \pm 0.7$ & $8.25^{\mathcal{c}} \pm 0.5$ \\
\hline \multirow[t]{2}{*}{20} & $11.20^{\mathrm{a}} \pm 0.67$ & $15.20^{\mathrm{b}} \pm 0.75$ & $10.53^{\mathrm{a}} \pm 0.80$ \\
\hline & $\begin{array}{l}\text { Plasma cholesterol } \\
\qquad(\mu \mathrm{g} / \mathrm{mL})\end{array}$ & & \\
\hline 10 & $335.56^{\mathrm{a}} \pm 6.3$ & $334.03^{\mathrm{a}} \pm 5.05$ & $420.11^{\mathrm{b}} \pm 4.99$ \\
\hline \multirow[t]{2}{*}{20} & $264.78^{\mathrm{a}} \pm 2.50$ & $309.03^{b} \pm 3.99$ & $268.58^{\mathrm{a}} \pm 2.04$ \\
\hline & $\begin{array}{l}\text { Liver AMP kinase } \\
\text { enzyme (ng/mg) }\end{array}$ & & \\
\hline 10 & $5.82^{a} \pm 0.67$ & $6.48^{\mathrm{a}} \pm 0.52$ & $5.03^{\mathrm{a}} \pm 0.60$ \\
\hline 20 & $4.07^{\mathrm{a}} \pm 0.51$ & $5.49^{\mathrm{a}} \pm 0.45$ & $2.04^{\mathrm{b}} \pm 0.28$ \\
\hline
\end{tabular}

${ }^{1} 10$ and 20 days represent days during exposure from 21 weeks of age at $39^{\circ} \mathrm{C}$ for $4 \mathrm{~h}$ under controlled conditions. ${ }^{2} \mathrm{CR}$ : control maintained at ambient room temperature, $\mathrm{CH}$ : control $(0 \mathrm{~g} \mathrm{FYC} / \mathrm{kg})$, and $\mathrm{SH}$ : treatment/ supplemented with $700 \mathrm{mg} / \mathrm{kg}$ of FYC. $\mathrm{CH}$ and $\mathrm{SH}$ group birds exposed to $39^{\circ} \mathrm{C}$ for $4 \mathrm{~h}$ under controlled conditions from 21 to 23 weeks of age. ${ }^{\mathrm{a}, \mathrm{b}, \mathrm{c}}$ In a row, values with different superscripts are significantly different from each other $(P<0.01)$. Values are represented as mean \pm SE. $N=6$ and 5 for hormone and enzyme studies, respectively.

TABLE 4: Body weight $(\mathrm{g})$ (mean $\pm \mathrm{SE})$ of Nicobari chickens subjected to different treatments.

\begin{tabular}{lccc}
\hline Weeks & $\mathrm{CR}^{1}$ & $\mathrm{CH}^{1}$ & $\mathrm{SH}^{1}$ \\
\hline $21^{2}$ & $1168.45^{\mathrm{a}} \pm 19.5$ & $1164.52^{\mathrm{a}} \pm 17.55$ & $1179.10^{\mathrm{a}} \pm 17.81$ \\
22 & $1240.46^{\mathrm{a}} \pm 15.29$ & $1247.21^{\mathrm{a}} \pm 11.29$ & $1304.96^{\mathrm{b}} \pm 14.58$ \\
23 & $1277.03^{\mathrm{a}} \pm 14.01$ & $1255.01^{\mathrm{a}} \pm 15.60$ & $1337.23^{\mathrm{b}} \pm 13.23$ \\
\hline Weeks & $\mathrm{CR}$ & $\mathrm{CH}$ & $\mathrm{SH}$ \\
$25^{3}$ & $1403.81^{\mathrm{a}} \pm 7.53$ & $1396.54^{\mathrm{a}} \pm 13.30$ & $1469.22^{\mathrm{b}} \pm 17.62$ \\
27 & $1480.11^{\mathrm{a}} \pm 12.37$ & $1505.30^{\mathrm{a}} \pm 16.20$ & $1564.31^{\mathrm{b}} \pm 15.23$ \\
29 & $1545.54^{\mathrm{a}} \pm 17.62$ & $1540.50^{\mathrm{a}} \pm 17.93$ & $1634.91^{\mathrm{b}} \pm 20.02$ \\
\hline
\end{tabular}

${ }^{1} \mathrm{CR}$ and $\mathrm{CH}$ : control $(0 \mathrm{~g} \mathrm{FYC} / \mathrm{kg})$. SH: treatment/supplemented with $700 \mathrm{mg} / \mathrm{kg}$ of FYC. CH and SH group birds exposed to $39^{\circ} \mathrm{C}$ for $4 \mathrm{~h}$ under controlled conditions from 21 to 23 weeks of age and also from 25 to 29 weeks after exposure. ${ }^{2}$ From 21 to 23 weeks of age, $\mathrm{CH}$ and $\mathrm{SH}$ group birds were exposed to $39^{\circ} \mathrm{C}$ for $4 \mathrm{~h}$ under controlled conditions. CR: birds exposed to normal ambient room temperature. ${ }^{3}$ From 25 to 29 weeks of age, all the groups were exposed to ambient temperature in the shed after exposure. ${ }^{a, b}$ In a row, values with different superscripts are significantly different from each other $(P<0.01) . N=10$.

chickens. Heat stress significantly reduced the feed intake $(P<0.01)$ in the $\mathrm{CH}$ group when compared to control treatment (CR). However, when Nicobari chickens (SH) received the supplementation, the feed intake was similar when compared to control treatment (CR) at 21 and 27 weeks but was significantly higher at other time intervals (22-25) (Table 5). Besides, supplementation with FYC increased the feed intake under heat stress.
TABLE 5: Feed intake (g) of Nicobari chickens subjected to different treatments.

\begin{tabular}{lccc}
\hline Weeks & $\mathrm{CR}^{1}$ & $\mathrm{CH}^{1}$ & $\mathrm{SH}^{1}$ \\
\hline $21^{2}$ & $59.83^{\mathrm{a}} \pm 1.4$ & $49.27^{\mathrm{b}} \pm 0.74$ & $58.76^{\mathrm{a}} \pm 0.75$ \\
22 & $53.80^{\mathrm{a}} \pm 0.97$ & $48.05^{\mathrm{b}} \pm 1.01$ & $60.99^{\mathrm{c}} \pm 1.08$ \\
23 & $52.63^{\mathrm{a}} \pm 0.49$ & $50.79^{\mathrm{a}} \pm 1.03$ & $56.01^{\mathrm{b}} \pm 0.67$ \\
\hline Weeks & $\mathrm{CR}$ & $\mathrm{CH}$ & $\mathrm{SH}$ \\
$25^{3}$ & $67.8^{\mathrm{a}} \pm 1.19$ & $63.84^{\mathrm{b}} \pm 0.94$ & $75.50^{\mathrm{c}} \pm 1.04$ \\
27 & $94.20^{\mathrm{a}} \pm 1.02$ & $77.7^{\mathrm{b}} \pm 0.90$ & $94.55^{\mathrm{a}} \pm 0.95$ \\
29 & $104.05^{\mathrm{a}} \pm 1.39$ & $77.03^{\mathrm{b}} \pm 0.99$ & $96.01^{\mathrm{c}} \pm 0.85$ \\
\hline
\end{tabular}

${ }^{1} \mathrm{CR}$ and $\mathrm{CH}$ : control $(0 \mathrm{~g} \mathrm{FYC} / \mathrm{kg}) . \mathrm{SH}$ : treatment/supplemented with $700 \mathrm{mg} / \mathrm{kg}$ of the FYC. CH and SH group birds exposed to $39^{\circ} \mathrm{C}$ for $4 \mathrm{~h}$ under controlled conditions from 21 to 23 weeks of age and also from 25 to 29 weeks after exposure. ${ }^{2}$ From 21 to 23 weeks of age, $\mathrm{CH}$ and $\mathrm{SH}$ group birds were exposed to $39^{\circ} \mathrm{C}$ for $4 \mathrm{~h}$ under controlled conditions. CR: birds exposed to normal ambient room temperature. ${ }^{3}$ From 25 to 29 weeks of age, all the groups were exposed to ambient temperature in the shed after exposure. ${ }^{\mathrm{a}, \mathrm{b}, \mathrm{c}}$ In a row, values with different superscripts are significantly different from each other $(P<0.01)$. Values are represented as mean $\pm \mathrm{SE}$. $N=10$ in each group.

Further, the study evaluated the effect of high ambient temperature on egg production (postexposure) from 23 to 30 weeks. Egg production started early in the SH group (23rd week), where an average of $6.6 \%$ of Nicobari chickens began to lay eggs, whereas the other two groups started later $(\mathrm{CR}=24$ th week; $\mathrm{CH}=25$ th week; Table 6$)$. Age at sexual maturity also showed the same trend $(161<168<175$ days). The percentage of egg production at 30 weeks for different groups was $70.32>59.63>57.23(\mathrm{SH}>\mathrm{CR}>\mathrm{CH})$. The rate of egg production was less in the $\mathrm{CH}$ group when compared to the other two groups.

3.5. Histological Studies. In the present experiment, mild (+) to medium $(++)$ necrotic condition of villi was observed in all groups of birds; percentage exhibiting mild necrosis was observed to be 80 and $85 \%$ in the CR and SH groups, respectively, when compared to the $\mathrm{CH}$ group (30\%). In contrast, the percentage of villi with medium necrotic effect (70\%) was observed more often in the $\mathrm{CH}$ group at both time intervals (Figure 1). The percentage of normal villi and villi with medium necrosis effect was 10 and $5 \%$ in $\mathrm{CR}$ and $\mathrm{SH}$ groups of chickens, respectively.

3.6. Gene Expression Studies. Expression of all hormone receptors was downregulated in the liver and magnum tissue of the supplemented group when compared to the $\mathrm{CH}$ group on day 10 (Figures 2-4), but on day 20, it was upregulated in the magnum tissue (Figures 2-4). On day 10, the difference in the fold change in the expression of hormone receptors of liver tissue between the $\mathrm{CH}$ and $\mathrm{SH}$ groups was not significant; however, it was significant $(P<0.05)$ only on day 20 ; it was significantly downregulated in the $\mathrm{SH}$ group.

\section{Discussion}

In the present experiment, the average cloacal temperatures of Nicobari pullets subjected to heat stress increased by $0.92^{\circ} \mathrm{C}(\mathrm{CH})$ and $1.02^{\circ} \mathrm{C}(\mathrm{SH})$ over that of the CR group of 
TABle 6: Effect of different treatments during exposure ${ }^{1}$ on the production of eggs (percentage) of Nicobari chickens during the postexposure period (laying period) $)^{2}$.

\begin{tabular}{lccc}
\hline Weeks & $\mathrm{CR}^{3}$ & $\mathrm{CH}^{3}$ & $\mathrm{SH}^{3}$ \\
\hline 23 & - & - & $6.6 \pm 0.12$ \\
24 & $7.51 \pm 0.11$ & - & $11.42 \pm 0.05$ \\
25 & $14.16 \pm 0.20$ & $11.10 \pm 0.21$ & $17.77 \pm 0.06$ \\
26 & $27.85^{\mathrm{a}} \pm 0.63$ & $34.54^{\mathrm{b}} \pm 0.58$ & $36.56^{\mathrm{c}} \pm 0.84$ \\
27 & $45.71^{\mathrm{a}} \pm 0.89$ & $49.20^{\mathrm{a}} \pm 0.97$ & $49.52^{\mathrm{a}} \pm 0.98$ \\
28 & $54.28^{\mathrm{a}} \pm 1.07$ & $55.89^{\mathrm{a}} \pm 0.71$ & $61.9^{\mathrm{b}} \pm 0.96$ \\
29 & $57.58^{\mathrm{a}} \pm 0.77$ & $57.23^{\mathrm{a}} \pm 1.32$ & $64.23^{\mathrm{b}} \pm 0.72$ \\
30 & $59.63^{\mathrm{a}} \pm 0.85$ & $70.32^{\mathrm{b}} \pm 0.74$ \\
\hline
\end{tabular}

${ }^{1}$ From 21 to 23 weeks of age, the $\mathrm{CH}$ and SH group birds were exposed to $39^{\circ} \mathrm{C}$ for $4 \mathrm{~h}$ under controlled conditions. CR: birds exposed to normal ambient room temperature. Mean \pm SEM values for a week are represented in percentage. ${ }^{2} \mathrm{Mean} \pm \mathrm{SEM}$ values for a week are represented in percentage. ${ }^{3} \mathrm{CR}$ and $\mathrm{CH}$ groups: control ( $0 \mathrm{~g} \mathrm{FYC} / \mathrm{kg})$. SH group: treatment/supplemented with FYC $(700 \mathrm{mg} / \mathrm{kg})$ from 23 to 30 weeks after exposure. ${ }^{\text {a,b,c }}$ Values with different superscripts are significantly different at least at $P<0.05$.

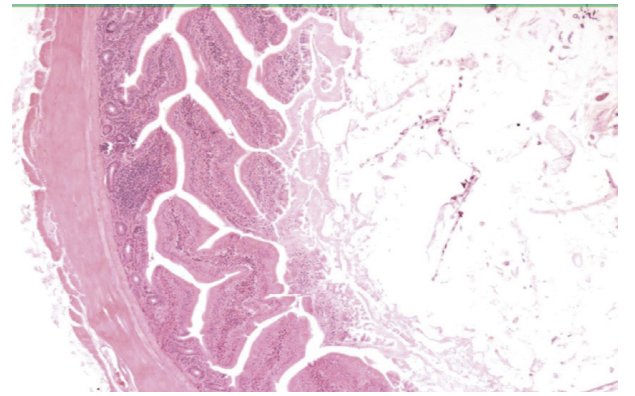

(a)

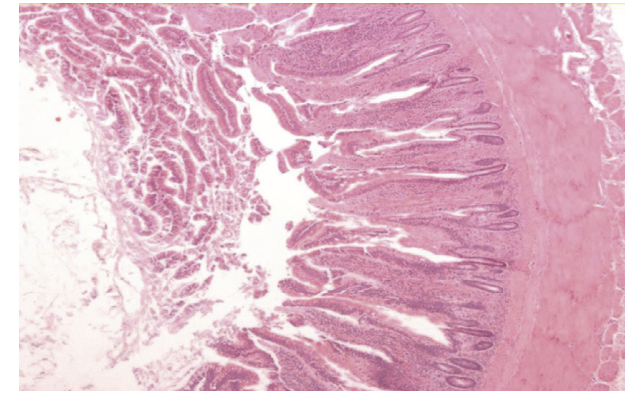

(b)

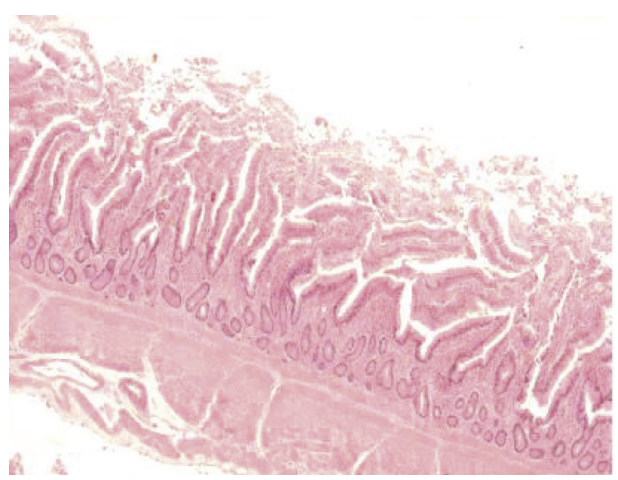

(c)

Figure 1: Histomorphology of the jejunum exhibiting. (a) Normal villi, (b) mild (+), and (c) medium (++) necrosis. Magnification: 400x.

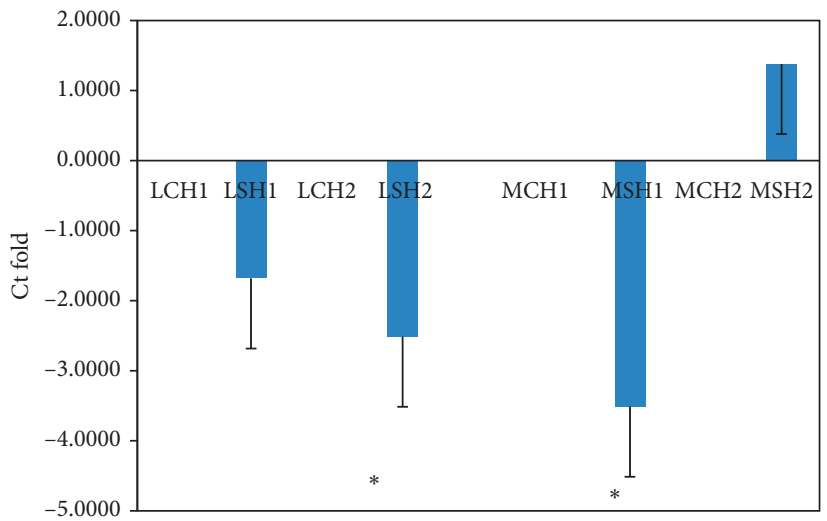

Figure 2: Comparison of relative fold change in the gene expression of leptin receptor (LEPR) in liver (L) and magnum (M) tissues of Nicobari chicken after $10 \mathrm{~d}\left(\mathrm{CH} 1\right.$ and SH1) and $20 \mathrm{~d}\left(\mathrm{CH} 2\right.$ and SH2) of the experiment. ${ }^{*} P<0.05$. C: control; S: supplemented with FYC at $700 \mathrm{mg} / \mathrm{kg} \mathrm{N}=4$. From 21 to 23 weeks of age, the $\mathrm{CH}$ and $\mathrm{SH}$ group birds were exposed to $39^{\circ} \mathrm{C}$ for $4 \mathrm{~h}$ under controlled conditions. 


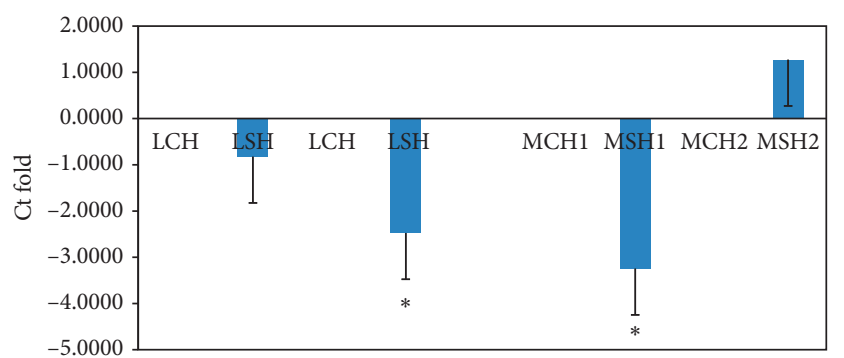

Figure 3: Comparison of relative fold change in the gene expression of ghrelin receptor (GSHR) in liver (L) and magnum (M) tissues of Nicobari chicken after $10 \mathrm{~d}(\mathrm{CH} 1$ and $\mathrm{SH} 1)$ and $20 \mathrm{~d}$ $(\mathrm{CH} 2$ and $\mathrm{SH} 2)$ of the experiment. C: control; S: supplemented with FYC at $700 \mathrm{mg} / \mathrm{kg} .{ }^{*} P<0.05 N=4$. From 21 to 23 weeks of age, the $\mathrm{CH}$ and $\mathrm{SH}$ group birds were exposed to $39^{\circ} \mathrm{C}$ for $4 \mathrm{~h}$ under controlled conditions.

birds. Chickens present an internal temperature of $41^{\circ} \mathrm{C}$, but an increase of $4^{\circ} \mathrm{C}$ or more above is considered fatal [43]. Basilio et al. [44] observed that, with an ambient temperature between 38 and $40^{\circ} \mathrm{C}$ and relative humidity between 50 and $55 \%$, a chicken's rectal temperature could be elevated to $45-48^{\circ} \mathrm{C}$ leading to death by heat stress and a decrease in production efficiency. Hence, the present study was conducted in Nicobari layers. Since India is a tropical country, and Nicobari is a native bird, continuous exposure to $39^{\circ} \mathrm{C}$ for $4 \mathrm{~h}$ might not have caused the rise in temperature, as reported in the earlier references. The mortality rate was $1 \%$ in the $\mathrm{CH}$ group, whereas in the other two groups, it was $0.5 \%$. Even then, we observed the effects of heat stress on the different parameters, such as a decrease in feed intake, body weight, and production of eggs of the $\mathrm{CH}$ group. Similar reports are available $[10,11]$.

Exposure to high temperature $\left(39^{\circ} \mathrm{C}\right.$ for $\left.4 \mathrm{~h}\right)$ decreased the mean level of hormones in the Nicobari birds when compared between the $\mathrm{CH}$ and $\mathrm{CR}$ groups. However, supplementation with $700 \mathrm{mg} / \mathrm{kg}$ of FYC could restore or increase the level of respective hormones in the $\mathrm{SH}$ group of birds. It was hypothesized that the level of hormones in the CR group was optimal for functions. The results obtained on days 10 and 20 were different. Mean levels of plasma leptin and ghrelin were significantly less in the $\mathrm{CH}$ group at both days 10 and 20, whereas the level of plasma GH was less only on day 20 when compared to respective hormone levels of $\mathrm{SH}$ and $\mathrm{CR}$ groups. Even though the plasma leptin level increased on day 20, it was still less when compared to the other two groups. Supplementation with FYC maintained the levels of leptin as observed in the CR group. This finding indicates that supplementation of FYC reduced the influence of heat stress on the levels of plasma leptin.

With respect to ghrelin hormone, supplementation of FYC could maintain a similar level only on day 10, but not on day 20, when compared to the CR group. Exposure to heat induces a decrease in plasma ghrelin levels [23]. In the $\mathrm{CH}$ group, even though the hormone level increased on day 20 compared to the level on day 10, it was still less compared to levels of plasma ghrelin in the other two groups. Ghrelin is known to stimulate feed intake in mammalian species while

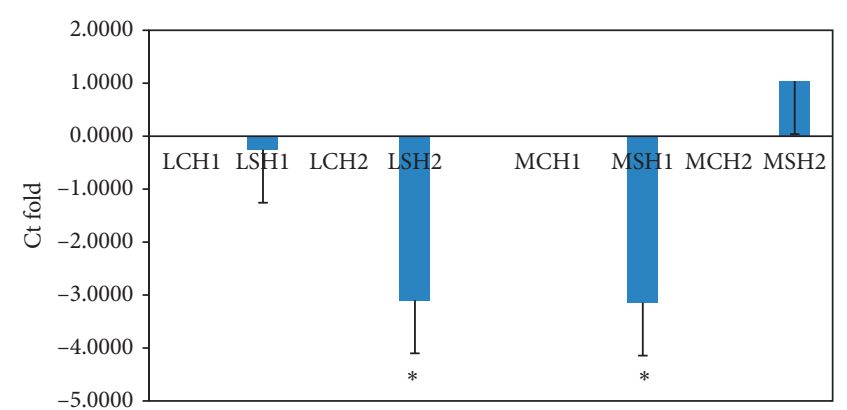

Figure 4: Comparison of relative fold change in the gene expression of ghrelin receptor (GHR) in liver (L) and magnum (M) tissues of Nicobari chicken after $10 \mathrm{~d}(\mathrm{CH} 1$ and SH1) and $20 \mathrm{~d}$ (CH2 and SH2) of the experiment. C: control; S: supplemented with FYC at $700 \mathrm{mg} / \mathrm{kg} .{ }^{*} P<0.05 N=4$. From 21 to 23 weeks of age, the $\mathrm{CH}$ and $\mathrm{SH}$ group birds were exposed to $39^{\circ} \mathrm{C}$ for $4 \mathrm{~h}$ under controlled conditions.

considering an anorexigenic hormone in chickens [45, 46]. In the present study, the relationship between the plasma levels of ghrelin and leptin on feed intake observed was not inversely related and the effect appeared to be independent. Instead, a decrease in FI became significant at a later stage during the postexposure period in the $\mathrm{CH}$ group, which is considered a delay in effect on FI. Ghrelin modulates the response to food cues via a neural network involved in regulating feeding and the appetitive response to food cues. Exposure to higher temperature increased plasma GH level significantly in both $\mathrm{CH}$ and $\mathrm{SH}$ groups when compared to $\mathrm{CR}$, indicating that the effect of FYC on $\mathrm{GH}$ at this time interval was not significant; but at day 20, the plasma GH level in the supplemented group was observed to be similar to the hormone levels observed in room temperature maintained birds. The GH level observed in room temperature birds was not significantly different from day 10 . Hence we can say that GH hormone level even though decreased in $\mathrm{SH}$ and $\mathrm{CH}$ groups, the level was comparable to the CR group. Hence supplementation of FYC was beneficial. However $\mathrm{GH}$ decreased significantly in $\mathrm{CH}$ group also, which was significant when compared with the other two groups. Chronic heat stress downregulated the mRNA expression of GH in liver [47]. The decrease in the level of all the hormones at 10 or $20 \mathrm{~d}$ of the $\mathrm{CH}$ group might have contributed to decreased production performance.

Supplementation of FYC caused the downregulation of expression of the receptors, LEPR, GSHR, and GHR for all the hormones in both liver and magnum tissues indicating reduced cellular activity. When the number of receptors decreases in response to rising hormone levels, called downregulation, cellular activity is reduced $([48,49]$. In the present experiment, the increase in hormone levels in the $\mathrm{SH}$ group might have downregulated the hormone receptors. The reduction in cellular activity might have also caused less energy requirement, bringing down the birds' metabolic activity. In the $\mathrm{CH}$ group, the opposite effect was observed on expression of receptors. It indicated the necessity of greater energy in these birds under heat stress [19]. The up- and downregulation of the receptors may be for maintaining homeostasis of the system [50]. In 
humans, it was observed that when there is an inflammatory condition of the liver, it may result in increased energy expenditure and reduced nutrition intake $[51,52]$. Similar results were obtained in the present study. Ghrelin receptors have been localized in the liver of chickens [53]. The expression pattern of ghrelin and its receptor $m R N A s$ was observed to change in liver depending on feeding states in poultry [54]. Since GH receptors have been localized in all regions of the oviduct and treatment of prelaying hens with $\mathrm{cGH}$ increased ovalbumin expression in magnum $[35,55]$, it can be suggested that an increase in plasma $\mathrm{GH}$ in FYC supplemented group during HS might have increased the function of magnum and other regions leading to increase in egg production. The same authors have reported that $\mathrm{GH}$ induces estrogen receptors; hence, this mechanism also might have led to an increase in egg production.

However, there have been very few reports on the association of ghrelin and leptin hormones in association with their activity on liver through their receptors during heat stress affecting production. Literature is not available with respect to the modulation of expression of mentioned hormone receptors in chickens subjected to heat stress. A supplement like FYC may maintain hormone levels and receptors' expression without causing a decrease in feed intake and production performance during HS.

Supplementation of FYC decreased the concentration of liver AMP kinase enzyme and was also less in the CR when compared to the $\mathrm{CH}$ group on day 20. These findings indicate a deficiency of energy in heat-stressed birds $(\mathrm{CH})$, and to compensate for the moderate decrease in feed intake, the concentration of liver AMP kinase enzyme increased. Similar results have been reported [56]. AMP kinase enzymes integrate nutritional and hormonal signals to promote energy balance by switching on catabolic pathways and switching off ATP-consuming pathways [57]. In response to stresses, ATP depletes, and the intracellular AMP : ATP ratio increases, resulting in the activation of AMPK $[58,59]$. Heat production may enhance hyperthermia, which may be detrimental to optimum body functions or production performance. Supplementation of FYC maintained metabolism reflecting less requirement of the enzyme.

Heat stress increases malondialdehyde level and decreases ROS-scavenging enzymes' activities and the levels of natural antioxidants in poultry $[60,61]$. YC supplementation decreased plasma MDA level. Heat stress causes hypoxic conditions, leading to less oxygen availability, and stress also leads to more ROS production, as evident by increased plasma MDA levels in the $\mathrm{CH}$ group compared to the other two groups. The increase of MDA concentration indicates damage by ROS [62]. Chronic HS showed a 1.2- to 1.5-fold increment in MDA [63, 64]. In the present experiment, also MDA levels increased 1.2-1.4-fold/ higher increment in the heat-stressed group compared to CR or $\mathrm{SH}$ groups, which indicates oxidative and inflammatory conditions. Hence, supplementation of yeast culture also proved to be beneficial as an antioxidant [65]. It has been proposed that the metabolites in yeast fermentation products may help balance the immune and stress responses and reduce free radical generation $[30,66]$.

The higher ambient temperature did not significantly affect the $\mathrm{CH}$ group's plasma cholesterol level compared to the levels of the CR group on day 10 of the experiment but by day 20, supplementation of FYC decreased plasma cholesterol when compared to $\mathrm{CH}$. Cholesterol is a heat stress marker [67] and dropped upon supplementation of FYC. Heat stress contributes to tight junction dysfunction and gross morphological changes that ultimately reduce intestinal barrier function $[26,68]$. A higher concentration of circulatory MDA in the $\mathrm{CH}$ group might have led to greater severity of necrosis of the jejunum when compared to the other two groups. In turn, this might have disturbed the absorption of nutrients across the digestive tract and the digestion, ultimately affecting production performance as reported by Zhao et al [69]. Mannan oligosaccharide (MOS), present on the outer layer of autolyzed yeast cell walls [70], prevents colonization of the pathogenic bacteria in the gut and improves the functional structure of intestines [71, 72]. It has also been reported that the use of XPC (YC product) can reduce physiological stress indicators in turkeys placed under short-term heat stress [73] and in broilers under longterm heat stress [74]. Thus supplementation of FYC proved to be beneficial in modulating physiological parameters.

Reduced feed intake during heat stress is an attempt to decrease metabolic heat production [75]. Heat stress induces an altered endocrine status and increased maintenance requirements [76], which results in a decrease in feed intake and energy available for production. The results revealed that the SH group birds consumed more feed from 21 to 25 weeks of age during and after exposure of the experimental tenure. An increase in feed intake might have led to better nutrient absorption, the balance of energy resulting in higher body weight of SH group birds, during and after exposure. Boswell and Dunn [77] affirm that the decline in food consumption occurs due to the heat's inhibitory action at the appetite center due to the high respiratory rate and reduced motility of the gastrointestinal tract, and this may be the reason for less FI in the $\mathrm{CH}$ group of birds.

During and after exposure to HS, the body weights of supplemented group birds were more when compared to the $\mathrm{CR}$ and $\mathrm{CH}$ groups of birds. This indicates that $\mathrm{HS}$ for $4 \mathrm{~h}$ for three weeks did not affect the body weight of the $\mathrm{CH}$ group. A decrease in feed intake and increase in the level of heat stress markers affected egg production only. A significant decrease in feed intake did not translate into decrease in BW but supplementation of FYC increased the FI and BW, compared to the other two groups. Since shortly after the postexposure period, when the laying period began and birds started laying eggs, the stress of the exposure and laying persisted in the $\mathrm{CH}$ group, leading to decreased egg production, and FYC supplementation overcame both stresses. Similar reports are available with respect to chickens reared in either natural or controlled environments [6, 13, 78-80]. Similarly, Christopher et al. [81] reported a $32.7 \%$ decrease in laying rate (82.9 versus $55.8 \%$ ) in heatstressed laying hens compared with hens reared under optimal thermal conditions. Similar results have also been reported in ducks [82]. A study conducted by Attia et al. [10] revealed that plasma hormones and the laying rate decreased in hens reared under heat stress when compared to the supplemented groups. FYC supplemented group delivered 
better results when compared to the CR group in terms of egg production in the shed even in the postexposure period. In our previous study [39], exposure to higher cyclic ambient temperature during summer decreased egg production in the nonsupplemented group compared to the FYC supplemented group. In the present study, the trend for the egg production performance was $\mathrm{CH}<\mathrm{CR}<\mathrm{SH}$.

\section{Conclusion}

In conclusion, an indigenous bird-like Nicobari changed its endocrine, metabolic, and gene expression parameters when subjected to higher ambient temperature $\left(39^{\circ} \mathrm{C}\right.$ for $\left.4 \mathrm{~h}\right)$. These heat stress effects were observed in terms of loss of production performance in the postexposure period also. The current study indicates that hormone levels, receptors expression, and metabolite levels can have an impact on the postexposure period. However, a supplement like FYC $(700 \mathrm{mg} / \mathrm{kg})$ provides a tool to negate adverse effects on production performance's by modulating physiological parameters.

\section{Data Availability}

The data used to support this study are available at https://krishi.icar.gov.in/jspui/handle/123456789/26059.

\section{Additional Points}

Exposure of Nicobari chickens to controlled higher ambient temperature decreased plasma level of hormones, increased heat stress markers, increased severity of necrotic condition of the jejunum, and increased expression of tissue hormone receptors. Supplementation of fermented yeast culture reversed the above effects and improved production performance during and after exposure.

\section{Conflicts of Interest}

The authors declare no conflicts of interest.

\section{Authors' Contributions}

A. L. Nidamanuri contributed to conceptualization, investigation, methodology, and project administration. Lawrence Leslie Leo Prince contributed to statistical analysis of data. Yadav S.P. contributed to validation and visualization. Bhattacharya T.K. assisted in writing original draft. S. R. R. Konadaka provided lab facilities for conducting experiments. Bhanja S. K. was responsible for the supervision of birds during the experiment.

\section{Acknowledgments}

The authors would like to acknowledge the financial assistance from ICAR-DPR for carrying out the research work as an institute research project. The authors would also like to acknowledge Mr. Rama Subbaiah, MSc., for assistance in carrying out different experiments.

\section{References}

[1] L. J. Lara and M. H. Rostagno, "Impact of heat stress on poultry production," Animal (Basel), vol. 3, pp. 356-369, 2013.

[2] S. Yahav, "Alleviating heat stress in domestic fowl: different strategies," World's Poultry Science Journal, vol. 65, pp. 719732, 2009.

[3] A. A. Kamboh and W. Y. Zhu, "Effect of increasing levels of bioflavonoids in broiler feed on plasma anti-oxidative potential, lipid metabolites and fatty acid composition of meat," Poultry Science, vol. 92, pp. 454-461, 2013.

[4] K. Sahin, C. Orhan, M. O. Smith, and N. Sahin, "Molecular targets of dietary phytochemicals for the alleviation of heat stress in poultry," World's Poultry Science Journal, vol. 69, pp. 113-123, 2013.

[5] J. J. Ajakaiye, A. B. Perez, and A. T. Mollineda, "Effects of high temperature on production in layer chickens supplemented with vitamins C and E," Revista MVZ Cordoba, vol. 16, pp. 2283-2291, 2011.

[6] M. M. Mashaly, G. L. Hendricks, M. A. Kalama, A. E. Gehad, A. O. Abbas, and P. H. Patterson, "Effect of heat stress on production parameters and immune responses of commercial laying hens," Poultry Science, vol. 83, pp. 889-894, 2004.

[7] M. U. Sohail, A. Ijaz, M. Younus et al., "Effect of supplementation of mannan oligosaccharide and probiotic on growth performance, relative weights of viscera, and population of selected intestinal bacteria in cyclic heat-stressed broilers," Journal of Applied Poultry Research, vol. 22, pp. 485-491, 2013.

[8] M. E. Abd El-Hack, A. Sameh, A. E. Abdelnour et al., "Herbs as thermoregulatory agents in poultry, an overview," Science of the Total Environment, vol. 703, p. 20, 2020.

[9] A. A. Ahmed, H. Abdullah, A. L. Yemni et al., "Effects of different dietary levels of blue lupine (Lupinus angustifolius) seed meal with or without probiotics on the performance, carcass criteria, immune organs, and gut morphology of broiler chickens," Frontiers in Veterinary Science, vol. 7, p. 124, 2020.

[10] Y. A. Attia, A. Abd El-Hamid, A. A. Abedalla et al., "Laying performance, digestibility and plasma hormones in laying hens exposed to chronic heat stress as affected by betaine, vitamin C, and/or vitamin E supplementation," Springerplus, vol. 5, p. 1619, 2016.

[11] Y. A. Attia and S. S. Hassan, "Broiler tolerance to heat stress at various dietary protein/energy levels," European Poultry Science, vol. 81, p. 171, 2017.

[12] A. Gouda, S. A. Amer, S. Gabr, and S. A. Tolba, "Effect of dietary supplemental ascorbic acid and folic acid on the growth performance, redox status, and immune status of broiler chickens under heat stress," Tropical Animal Health and Production, vol. 52, pp. 2987-2996, 2020.

[13] L. Liu, M. Ren, K. Ren, Y. Jin, and M. Yan, "Heat stress impacts on roilererformance: a systematic review and metaanalysis," Poultry Science, vol. 99, pp. 6205-6211, 2020.

[14] E. Mario and M. Petracci, "Benefits of magnesium supplementation to broiler subjected to dietary and heat stress: improved redox status, breast quality and decreased myopathy incidence," Antioxid. (Basel, Switzerland), vol. 8, p. 456, 2019.

[15] G. Sandner, A. S. Mueller, X. Zhou et al., "Ginseng extract ameliorates the negative physiological effects of heat stress by supporting heat shock response and improving intestinal barrier integrity: evidence from studies with heat-stressed 
caco-2 cells, C. elegans and growing broilers," Molecules (Basel, Switzerland), vol. 25, p. 835, 2020.

[16] S. Wasti, N. Sah, and B. Mishra, "Impact of heat stress on poultry health and performances, and potential mitigation strategies," Animal, vol. 10, p. 1266, 2020.

[17] S. A. Elgeddawy, H. M. Shaheen, Y. S. El.Sayed et al., "Effects of the dietary inclusion of a probiotic or prebiotic on florfenicol pharmacokinetic profile in broiler chicken," Journal of Animal Physiology and Animal Nutrition, vol. 104, pp. 549557, 2020.

[18] E. O. S. Hussein, G. M. Suliman, A. N. Alowaimer et al., "Growth, carcass characteristics, and meat quality of broilers fed a low-energy diet supplemented with a multienzyme preparation," Poultry Science, vol. 99, pp. 1988-1994, 2020.

[19] Y. A. Attia, A. Mohammed, and A. S. Elnaggar, "Productive, physiological and immunological responses of two broiler strains fed different dietary regimens and exposed to heat stress," Italian Journal of Animal Scienc, vol. 17, pp. 686-697, 2018.

[20] W. C. Wang, F. F. Yan, J. Y. Hu, O. A. Amen, and H. W. Cheng, "Supplementation of Bacillus Subtilis-based probiotic reduces heat stress-related behaviors and inflammatory response in broiler chickens," Journal of Animal Science, vol. 96, pp. 1654-1666, 2018.

[21] X. He, Z. Lu, B. Ma et al., "Effects of dietary taurine supplementation on growth performance, jejuna morphology, appetite-related hormones, and genes expression in broilers subjected to chronic heat stress," Poultry Science, vol. 98, pp. 2719-2728, 2019.

[22] R. Churm, J. S. Davies, J. W. Stephens, and S. L. Prior, "Ghrelin function in human obesity and type 2 diabetes: a concise review," Obesity Reviews, vol. 18, pp. 140-148, 2017.

[23] C. Faure, K. Charlot, S. Henri, M. D. Hardy-Dessources, O. Hue, and S. Antoine-Jonville, "Effect of heat exposure and exercise on food intake regulation: a randomized crossover study in young healthy men," Metabolism: Clinical and Experimental, vol. 65, pp. 1541-1549, 2016.

[24] D. Carling, M. J. Sanders, and A. Woods, "The regulation of AMP-activated protein kinase by upstream kinases," International Journal of Obesity, vol. 32, no. 4, pp. S55-S59, 2008.

[25] B. D. Hegarty, N. Turner, G. J. Cooney, and E. W. Kraegen, "Insulin resistance and fuel homeostasis: the role of AMPactivated protein kinase," Acta Physiologica, vol. 196, pp. 129-145, 2009.

[26] G. P. Lambert, C. V. Gisolfi, D. J. Berg, P. L. Moseley, L. W. Oberley, and K. C. Kregel, "Selected contribution: hyperthermia-induced intestinal permeability and the role of oxidative and nitrosative stress," Journal of Applied Physiology, vol. 92, pp. 1750-1761, 2002.

[27] A. A. AL-Sagan, S. Khalil, E. O. S. Hussein, and Y. A. Attia, "Effects of fennel seed powder supplementation on growth performance, carcass characteristics, meat quality, and economic efficiency of broilers under thermoneutral and chronic heat stress conditions," Animal, vol. 10, p. 206, 2020.

[28] Credence Research, Inc., Global Prebiotics Market - Growth, Future Prospects, and Competitive Analysis, Credence Research, Inc., Maharashtra, India, 2018.

[29] P. Spring, C. Wenk, A. Connolly, and A. Kiers, "A review of 733 published trials on Bio-MOS, a mannan oligosaccharide, and Actigen, a second generation mannose rich fraction, on farm and companion animals," Journal of Applied Animal Nutrition, vol. 3, pp. 1-11, 2015.

[30] G. S. Jensen, K. M. Patterson, and I. Yoon, "Yeast culture has anti-inflammatory effects and specifically activates NK cells,"
Comparative Immunology, Microbiology \& Infectious Diseases, vol. 31, pp. 487-500, 2008.

[31] Z. Rehman, N. Chand, and R. U. Khan, "The effect of vitamin $\mathrm{E}, \mathrm{L}$-carnitine, and ginger on production traits, immune response, and antioxidant status in two broiler strains exposed to chronic heat stress," Environmental Science and Pollution Research, vol. 24, pp. 26851-26857, 2017.

[32] D. M. Denbow, "Gastrointestinal anatomy and physiology," in Sturkie's Avian Physiology, G. C. Whittow, Ed., Academic Press, New York, NY, USA, 2000.

[33] S. Cassy, M. Derouet, S. Crochet, S. Dridi, and M. Taouis, "Leptin and insulin down regulate leptin receptor gene expression in chicken-derived leghorn male hepatoma cells," Poultry Science, vol. 82, no. 10, pp. 1573-1579, 2003.

[34] N. Sah, D. Lee Kuehu, V. Singh Khadka et al., "RNA sequencing-based analysis of the magnum tissues revealed the novel genes and biological pathways involved in the egg-white formation in the laying hen," BMC Genomics, vol. 22, p. 318, 2018.

[35] A. Hrabia, A. K. Grzegorzewska, and A. Sechman, "Expression and localization of growth hormone receptor in the oviduct of the laying hen (Gallus domesticus)," Folia Biologica (Kraków), vol. 61, pp. 271-276, 2013.

[36] S. C. Mohapatra and B. Panda, "Poultry genetic resources of India," Poultry Science, vol. 5, pp. 1-10, 1981.

[37] S. P. S. Ahlawat and R. N. Chatterjee, "Conservation of indigenous poultry germplasm of A and N Islands," in Proceedings of National Workshop on Characterization and Conservation of Indigenous Poultry Germplasm, pp. 9-14, Central Agriculture Research Institute, Port Blair, Andaman, May 2002.

[38] A. K. Panda, S. V. Rama Rao, M. V. L. N. Raju, M. Niranjan, and M. R. Reddy, "Effect of nutrient density on production performance, egg quality and humoral immune response of brown laying (Dahlem Red) hens in the tropics," Tropical Animal Health and Production, vol. 44, pp. 293-299, 2012.

[39] N. Anand Laxmi, L. L. L. Prince, K. Rama Subbaiah, and R. K. Mahapatra, "Relationship between plasma GH, metabolites, lipogenic genes and MMP3 expression in different tissues of PD3 chicken line during summer season and role of fermented yeast culture in alleviating heat stress," Journal of Applied Poultry Research, vol. 99, pp. 1-10, 2019.

[40] W. Quinteiro-Filho, M. A Ribeiro, V. Ferraz-de-Paula, and M. Pinheiro, "Heat stress impairs performance parameters, induces intestinal injury, and decreases macrophage activity in broiler chickens," Poultry Science, vol. 89, pp. 1905-1914, 2010.

[41] K. J. Livak and T. D. Schmittgen, "Analysis of relative gene expression data using real-time quantitative PCR and the 2(delta delta C(T)) method," Methods, vol. 25, pp. 402-408, 2001.

[42] SPSS, SPSS for Windows, Brief Guide, Version 12.0, SPSS Inc, Chicago, IL, USA, 2004.

[43] DEFRA, Heat Stress in Poultry: Solving the Problem, Department for Environment, Food \& Rural Affairs, London, UK, 2005.

[44] V. de. Basilio, M. Vilariño, A. Leon, and M. Picard, "Efecto de la aclimatacion precoz sobre la termotolerancia en pollos de engorde sometidos a un estres termico tardio en condiciones de clima tropical," Revista Cientifica- Universidad Del Zulia Facultad de Ciencias Veterinarias Division de Investigacion Universidad del Zulia, vol. 11, pp. 60-68, 2001.

[45] N. Everaert, E. Decuypere, and J. Buyse, W. H. Hendriks and M. W. A. Verstegen, Chapter 3: feed intake and regulation," in 
Book Poultry and Pig Nutrition Challenges of the 21st centuryWageningen Academic Publisher, Wageningen, Netherlands, 2019.

[46] M. Kojima, H. Hosoda, Y. Date, M. Nakazato, H. Matsuo, and K. Kangawa, "Ghrelin is a growth-hormone-releasing acylated peptide from stomach,” Nature, vol. 402, pp. 656-660, 1999.

[47] E. M. Roushdy, A. W. Zaglool, and M. S. El-Tarabany, "Effects of chronic thermal stress on growth performance, carcass traits, antioxidant indices and the expression of HSP70, growth hormone and superoxide dismutase genes in two broiler strains," Journal of Thermal Biology, vol. 74, pp. 337-343, 2018.

[48] H. Shankaran, H. S. Wiley, and H. Resat, "Receptor downregulation and desensitization enhance the information processing ability of signalling receptors," BMC Systems Biology, vol. 1, p. 48, 2007.

[49] C. Walther and S. S. Ferguson, "Arrestins: role in the desensitization, sequestration, and vesicular trafficking of $\mathrm{G}$ protein-coupled receptors," Progress in Molecular Biology and Translational Science, vol. 118, pp. 93-113, 2013.

[50] S. R. M. Maddineni, O. Krzysik-Walker, G. L. Hendricks, and R. Ramachandran, "Gonadotropin-inhibitory hormone $(\mathrm{GnIH})$ receptor gene is expressed in the chicken ovary: potential role of $\mathrm{GnIH}$ in follicular maturation," Reprod, vol. 135, pp. 267-274, 2008.

[51] C. Gerstner, T. Schuetz, V. Von Baehr et al., "Correlation between energy expenditure, nutrient intake, malnutrition and activa-tion of the inflammatory system in patients with hepatic cir-rhosis," Journal of Hepatology, vol. 34, pp. 195-196, 2001.

[52] A. Huseyin, I. H. Bahcecioglu, N. Kuzu et al., "The levels of ghrelin, leptin, TNF- $\alpha$, and IL-6 in liver cirrhosis and hepatocellular carcinoma due to HBV and HDV infection," Mediators of Inflammation, vol. 78380, pp. 1-6, 2006.

[53] M. P. Richards, S. M. Poch, and J. P. McMurtry, "Characterization of Turkey and chicken ghrelin genes, and regulation of ghrelin and ghrelin receptor mRNA levels in broiler chickens," General and Comparative Endocrinology, vol. 145, pp. 298-310, 2006.

[54] L. L. Chen, Q. Y. Jiang, X. T. Zhu et al., "Ghrelin ligandreceptor mRNA expression in hypothalamus, proventriculus and liver of chicken (Gallus gallus domesticus): studies on ontogeny and feeding condition," Comparative Biochemistry and Physiology, vol. 147, pp. 893-902, 2007.

[55] A. Hrabia, A. Leśniak-Walentyn, A. Sechman, and A. Gertler, "Chicken oviduct-the target tissue for growth hormone action: effect on cell proliferation and apoptosis and on the gene expression of some oviduct-specific proteins," Cell and Tissue Research, vol. 357, pp. 363-372, 2014.

[56] Y. A. Attia, M. Barbara, and D. Böhmer, A. Roth-Maier, Responses of broiler chicks raised under constant relatively high ambient temperature to enzymes, amino acid supplementations, or a high-nutrient diet," Archiv für Geflügelkunde, vol. 70, pp. 80-91, 2006.

[57] B. Viollet, F. Marc, G. Bruno et al., "Activation of AMPactivated protein kinase in the liver: a new strategy for the management of metabolic hepatic disorders," The Journal of Physiology, vol. 574, pp. 41-53, 2006.

[58] D. G. Hardie, "The AMP-activated protein kinase pathway-new players upstream and downstream," Journal of Cell Science, vol. 117, pp. 5479-5487, 2004.

[59] D. G. Hardie, "AMP-activated protein kinase: an energy sensor that regulates all aspects of cell function," Genes \& Development, vol. 25, pp. 1895-1908, 2011.
[60] M. Gopi, M. R. Purushothaman, and D. Chandrasekaran, "Influence of coenzyme Q10 supplementation in high energy broiler diets on production performance, hematological and slaughter parameters under higher environmental temperature," Asian Journal of Animal and Veterinary Advances, vol. 10, pp. 311-322, 2015.

[61] R. P. Rhoads, L. H. Baumgard, J. K. Suagee, and S. R. Sanders, "Nutritional interventions to alleviate the negative consequences of heat stress," Advances in Nutrition, vol. 4, pp. 267-276, 2013.

[62] S. Wang, P. Song, and H. H. Zou, "AMP-activated protein kinase, stress responses and cardiovascular diseases," Clinical Science, vol. 122, pp. 555-573, 2012.

[63] A. Akbarian, J. Michiels, J. Degroote, M. Majdeddin, A. Golian, and S. De Smet, "Association between heat stress and oxidative stress in poultry; mitochondrial dysfunction and dietary interventions with phytochemicals," Journal of Animal Science and Biotechnology, vol. 7, p. 37, 2016.

[64] M. Toyomizu, M. A. K. Azad, M. Kikusato, T. Maekawa, and Shirakawa, "Metabolic characteristics and oxidative damage to skeletal muscle in broiler chickens exposed to chronic heat stress," Comparative Biochemistry and Physiology Part Biochemistry and Physiology Part A: Molecular \& Integrative Physiology, vol. 155, pp. 401-406, 2010.

[65] Y. A. Attia, H. Al-Khalaifah, A. E. Abd El-Hamid, and M. A. Al-Harthia, "Growth performance, digestibility, intestinal morphology, Carcass traits and meat quality of broilers fed marginal nutrients deficiency-diet supplemented with different levels of active Yeast," Livestock Science, vol. 223, p. 10, Article ID 103945, 2020.

[66] J. D. Firman, D. Moore, J. Broomhead, and D. McIntyre, "Effects of dietary inclusion of a Saccharomyces cerevisiae fermentation product on performance and gut characteristics of male turkeys to market weight," International Journal of Poultry Science, vol. 12, pp. 141-143, 2013.

[67] M. F. Gursu, M. Onderci, F. Gulcu, and K. Sahin, "Effects of vitamin $C$ and folic acid supplementation on serum paraoxonase activity and metabolites induced by heat stress in vivo," Nutrition Research, vol. 24, pp. 157-164, 2004.

[68] I. Palamidi, K. Fegeros, M. Mohnl et al., "Probiotic form effects on growth performance, digestive function, and immune related biomarkers in broilers," Poultry Science, vol. 95, pp. 1598-1608, 2016.

[69] H. Zhao, Y. He, S. Li et al., "Subchronic arsenism-induced oxidative stress and inflammation contribute to apoptosis through mitochondrial and death receptor dependent pathways in chicken immune organs," Oncotarget, vol. 8, pp. 40327-40344, 2017.

[70] M. J. Van der Werf, MOS Products: Not Every Yeast Cell Wall is Created Equal. Ohly Application Note, https://www.ohly. com/en/feed-health, 2019.

[71] J. Fowler, R. Kakani, A. Haq, J. A. Byrd, and C. A. Baily, "Growth promoting effects of prebiotic yeast cell wall products in starter broilers under an immune stress and Clostridium perfringens challenge," Journal of Applied Poultry Research, vol. 24, pp. 66-72, 2015.

[72] S. Kwiatkowski and E. Kwiatkowski, "Yeast (Saccharomyces cerevisiae) glucan polysaccharides - occurrence, separation and application in food, feed and health industries," in The Complex World of Polysaccharides, D. N. Karunaratne, Ed., InTech, London, UK, 2012.

[73] B. M. M. S. Bartz, Effects of Induced Stress on Turkey Hens Supplemented with Yeast Derived Fermentation Products, University of North Carolina, Raleigh, NC, USA, 2016. 
[74] P. T. Price, J. A. Byrd, C. Z. Alvarado, H. O. Pavlidis, D. R. McIntyre, and G. S. Archer, "Utilizing original XPC ${ }^{\mathrm{TM}}$ in feed to reduce stress susceptibility of broilers," Poultry Science, vol. 97, pp. 855-859, 2018.

[75] L. H. Baumgard and R. P. Rhoads, "Ruminant nutrition symposium: ruminant production and metabolic responses to heat stress," Journal of Animal Science, vol. 90, pp. 1855-1865, 2012.

[76] R. J. Collier, L. H. Baumgard, A. L. Lock, and D. E. Bauman, "Physiological Limitations: nutrient partitioning in yields of farmed species: constraints and opportunities in the 21st century," in Proceedings: 61st Easter School, J. Wiseman and R. Bradley, Eds., pp. 351-377, Nottingham University Press, Nottingham, UK, 2005.

[77] T. Boswell and I. C. Dunn, "Regulation of agouti-related protein and pro-opiomelanocortin gene expression in the avian arcuate nucleus," Frontiers in Endocrinology, vol. 8, p. 75, 2017.

[78] A. O. Oguntunji, F. A. Aderemi, T. E. Lawal, and O. M. Alabi, "The Influence of seasonal variation on performance of a commercial laying strain in a derived savanna environment in Nigeria," International Journal of Poultry Science, vol. 5, pp. 67-74, 2008.

[79] I. Rozenboim, E. Tako, O. Gal-Garber, J. A. Proudman, and Z. . Uni, "The effect of heat stress on ovarian function of laying hens," Poultry Science, vol. 86, pp. 1760-1765, 2007.

[80] A. Yakubu, A. E. Salako, and A. O. Ige, "Effects of genotype and housing system on the laying performance of chickens in different seasons in the semi-humid tropics," International Journal of Poultry Science, vol. 6, pp. 434-439, 2007.

[81] D. M. Christopher, K. R. Bramwell, J. L. Wilson, and B. Howarth, "Fertility of male and female broiler breeders following exposure to elevated ambient temperatures," Poultry Science, vol. 74, pp. 1029-1038, 1995.

[82] X. Luo, C. Zheng, W. Xia et al., "Effects of constant or intermittent high temperature on egg production, feed intake, and hypothalamic expression of antioxidant and pro-oxidant enzymes genes in laying ducks," Journal of Animal Science, vol. 96, pp. 5064-5074, 2018. 